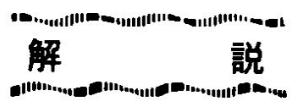

\title{
非定常遷音速空気力と空力弾性 ${ }^{* 1}$
}

$$
\text { アール H. ダウエル*2 }
$$

Key Words : Aeroelasticity, Unsteady Flows, Transonic Flows

\section{概 要}

四つのおもだった疑問について議論する．

・空気力が、本質的に置の運動の線形関数になる のは，どのような条件下であろうか。

・空気力が，翼の運動に対して非線形関数である という場合に，時にみられる，多価解(非一義解) は，どういう意味をもつのか.

- 流体運動の方程式を解く，差分法にとって代わ るような有望な手法は，あるだろうか

・空力弾性 (たとえばフラッタ)の解析において, 非定常僄音速空気力計算機コードを使ったとき， 確かで効率の良い計算手法は，何であろうか。

\section{1.はじめに}

概要に揭げた，四つの質問を，この論文の骨子とな るように選んでみた。こう選んだのには、いくつか理 由がある。

・ これらは，重要であり続けると思われる基本的 な疑問であること。

・ これらの㸷問に対する解答には，非定常遷音速 空気力を空力弾性問題に適用することに関して，

重要な帰結を含んでいること.

- 最近の研究は，少なくとも部分的に，これらに

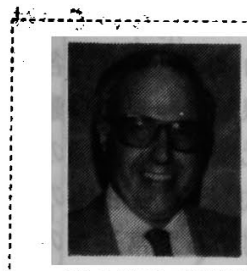

者紹介

アール H. タウエル (Earl H. Dowell) 1964 年 MIT において Sc. D. 取得. MIT 助教授、ブリンスト ン大学教授を経, 1983 年工学部長 としてデューク大学教授，現在に至

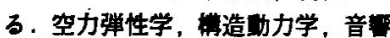
学の分野の研究者として知られる.アメリ力航空字宙 学会 SDM 学会黄受賞. 昭和 59 年 11 月日本学術振舆 会の招へいて来日.

・昭和 59 年 11 月 27 日，第 22 回飛行機シンポジムて特別 誰演. 昭和 60 年 6 月 29 日原稿受理 Unsteady Transonic Aerodynamics and Aeroelasticity

-2 Earl H. DOWELL デューク大学工学部曼 㺲跀：上田接彦（航空宇宙技術研究所）
対する答をひきだしていること．

しかしながら，これらの質問が．決して興味ある疑 問のすべてを尽しているわけではない，

- 粘性や流れの剥離の重要な効果とか

・差分解法で遂げた，意義深い進歩，およびそれ にひき続く，遷音速流れのより高度な物理的解釈 などといったいくつかの䂑問については．幸いにして

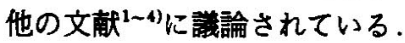

四つの質問を，それぞれ，2，3，4，5章で論じる。 各章は，他の章とは比較的独立して読むことができる ので，読者には，適宜それを活かしていただきたい．

\section{2. 非定常逗音速流れの線形/非線形挙功}

2.1 功機と一杸的な背景 空力弾性屋達は，ほと んどの空力弾性問題の解析に, 動的線形系としての理 論を用いている。なぜそうするのか. その動機は明白 である．これまて，多くの経験，解积，そして有効な 計算／実験手順といったものが，線形系についてなさ れてきた。これに対し, 非線形の解析や実験手法は, 使えたとしても，その結果を得る段になると，とてつ もなく高価なものについたり，また，解釈することが かなりむずかしくなったりする．こうしたことで，線 形モデルは，適用さえできれぱ，非常に強力で，比較 的単純て，しかもきわめて有用なのである。したがっ て，その線形モデルの有効範囲を見定めることが，非 常に重要となってくる.

ここでいま，われわれが対象とするのは，遷音速流 れで実際に起こりうる, 空力的非線形性についてであ る.もちろん, 空力的な非線形性は，他の流れの領域 でも起こるであろう.が，しかし，それが最も重要な ことになりそうなのは遷音速流れである，事実，遷音 速流れの領域では，その場の支配方程式が，本質的に 非線形であることがしばしば起こる。しかし、いかな る型，いかなるマッ八数においても，もし迎角が十 分に小さければ，空気力ゃ衝撃波の運動は，迎角に関 して線形となるであろう。ささらに，迎角変動の振動数 が増すにつれて、線形挙動とみなされる迎角の篗囲が 拡がる、ということがいえる。おもな解析手段とし 


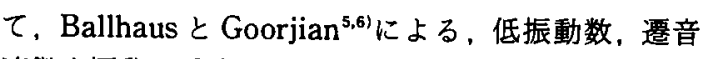
速微小擾乱の手法 (LTRAN 2) を用い，どのくらいま で線形で，どこから非線形になるのか，ということを 調べるのを，ここでの目的とする．既存の，あるいは 将来のどんな非線形の空気力計算法でも，同様の目的 に使うことができる(また，そうするべきでもある)。

まず、衝撃波とその動きについて議論するのが、理 解の手助けになるだろう。これは，しばしば混乱のも とになるものである. 変動迎角についての定常微小擾 乱空気力の理論では,どの適合“線形化の結論も，集 中荷重あるいは(しばしば, ショック・ダブレットと 呼ばれる) 圧力パルスが，定常状態の衝撃波位置に現 れる78)ことをいっている. 圧力パルスの強さは，定 常衝撃波の圧力跳躍に等しく、またその変動幅は，変 動迎角の大きさに比例する．これに対し，翼弦の他の 部分（定常衝撃波の位置に中心をもつショック・ダフ レットから離れた所）では，压力の振幅が（線形遷音 速理論において）変動迎角に比例し，変動迎角が小さ くなるにつれて，比例して小さくなる．もちろん，後 者の振舞は，古典理論でも同じでる. 古典的線形理 論と遷音速線形理論の最も重要な(これだけではない が）相違点は，後者における衝撃波の存在（とその運 動）であり，それは，集中した衝撃力ダブレットを生 じさせることにある. LTRAN 2 や他の遷音速計算機 コードは，衝撃波とその運動をともに含んでいるが， 古典的な空気力学理論はそのどちらも含んでいな い、いくつかの，非適合な遷音速手法では，衝撃波の 存在は含んでいるが，その運動は含まれていない.

これらの振舞いは，変動迎角が小さくなった場合の 非線形動力学理論でも見ることができる. LTRAN 2 を使って得た第 1 図を考えてみよう。これには，いく つかの迎角に对して， $M_{\infty}=0.86 て ゙ の ， N A C A 64$ A 006 翼型の翼弦方向差压分布 (下面から上面を引い たもの）を示してある。ここでは，簡単のため，定常 と非定常の差を（数值的に）なくするように，無次元 振動数をぜロとしている， $\alpha=0.125^{\circ}$ とか $0.25^{\circ}$ とか いつた小さな迎角で見られるように，圧力分布には， 平均 (迎角) 衝擊波位置, $x_{\mathrm{s}}=0.584$ まわりのショッ ク・タフフレットが現われる.ショック・ダブレットの 幅は綎線で示してあり，前方のものは下面にあるもの で, 後方のものは上面に位置するものである．この幅 は，微小の $\alpha$ においては， $\alpha$ に比例する.しかし， $\alpha$ が増加し，1゚に近づくにつれ，下面の衛撃波は消隇

\footnotetext{
“（訳注）変動空気力成分を高く場合，行繁波の位置の変化 を考慮してあるものを道合 (consistent) と呼び，衙暂波位

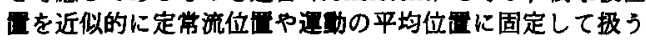
ものを非適合（inconsistent）と呼んている。
}

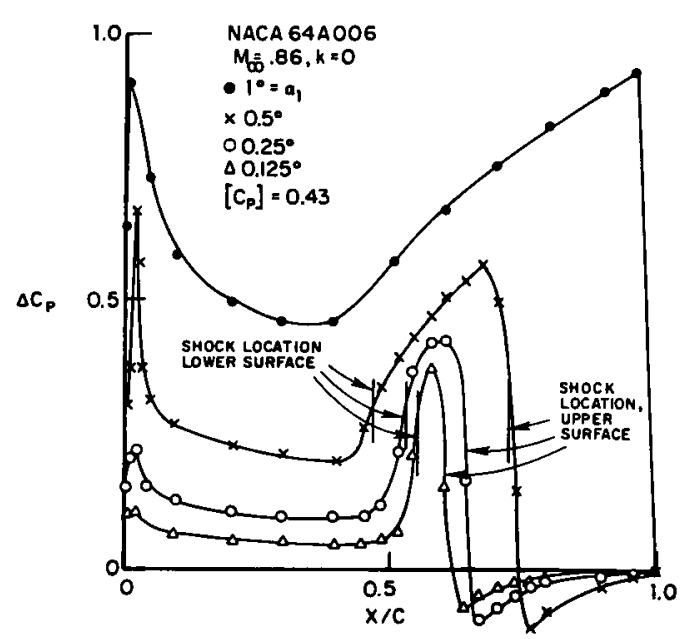

第 1 図差圧 分布

し，上面の衝擊波は後緑に向かい，そこに留まる，小 さな $\alpha$ に対しては，また，ショック・ダブレットの強 さが， $\alpha=0$ で衝撃波前後の圧力跳躍を本䝯的に等 しく，すなわち 0.43 である. ショック・ダブレットを 離れたところでは，圧力は，小さい $\alpha て ゙ \alpha に$ 比例し ている，最後に，実用上重要なことであるが，小さな

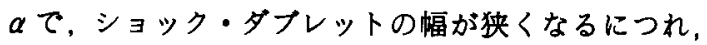

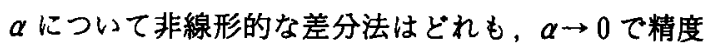
上の問題を生じる.これに対して，あらかじめ $\alpha に$ ついて線形化する方法では，衝擊波の運動を陽的に計 算するため，こういった障害を避けることができる (たとえばWilliams ${ }^{7,8)}$ p Fung 等9)を参照)。また、理 論と実験の洞察力のある評価については，Tijdeman" や. Tijdeman と Seebass ${ }^{21} の$ 議論を参照されたい. Davis と Malcolm ${ }^{10)}$ の実験的研究は，上記の確証を はっきりと与えており，ここでの議論にはとくに適切 なものである。

$2.2 M_{\infty}=0.86$ ，前緑まわりにピッチング運符する NACA 64 A 006 型型 おもに次の事柄について検討 された ${ }^{111}$. 動的空気力と衝撃波の動きに対する，各無 次元振動数での変動迎角の影䇾; 線形/非線形挙動の 境界 : 空力伝達関数に対する無次元振動数と振幅の影 稫：定常空気力と衝擊波位置に対する変動迎角の影 響；動的空気力と街擊波の動きに対する定常迎角の影 嘒。ここでは，紙面の都合により．初めの 2 件のみを 考えるにとどめる。

\section{3 功的な力と衙慗波の功きに対する变㨁迎角の}

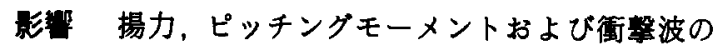
運動が比較的線形てあると見なせるか，それとも非線 形であるのかを決めるため，どのくらいの振幅になる と非線形効果が卓越してくるのか，を眺めてみたい． 
全体の揚力（モーメント，衝擊波の運動も同様）が、 $C_{\mathrm{L}}=C_{\mathrm{L} 0}+C_{\mathrm{L} 1}$ と分解されることに注意する。こ て， $C_{\mathrm{LO}}$ は，平均迎角 $\alpha_{0}$ による揚力， $C_{\mathrm{L} 1}$ は，与え られた $\alpha_{0}$ まわりの，変動迎角による揚力と定義する. 古典的線形理論 (遷音速線形理論ではない)では， $C_{\mathrm{L} 1}$ は $\alpha_{0}$ に独立である。

第 2 図では，無次元振動数，k=0.2について，揚 力，ピッチング・モーメントおよび衙擊波の変位が. 変動迎角 $\alpha_{1}$ の関数として示されている，揚力および モーメント係数は，通常の定義によるものて，モーメ ントは翼弦中心まわりにとった，衝撃波の変位は，翼 弦長で無次元化してある。

揚力は，モーメントに比べて大きな振幅に至るまで 線形性を保持する傾向にあり，一方，モーメントは， 衛撃波に比べると、より大きな振幅まで線形性を保つ 傾向にあることがわかる，さらに，後で述べるか，無 次元振動数が高くなればなるほど，線形挙動の範囲は 拡がってくる．どの数值結果においても，検知できる ほどの高次調和成分は，なかったことを注意したい． 結果は，揚力，モーメント，および衝撃波運動につい て，実質的に単振動であった：したがって，振幅や位 相の決定は，いくつかの既存の方法のどれによって も，ただちに行うことができた。

\section{4 線形/非線形举動の境界 第 2 図に示すよう} な結果を使って、線形/非線形の境界線を、マッ八数 対賈の振幅といった形で作ることができる．線形から はずれた，という規準は，衝撃波変位量が。0.05 翼 弦長を越える点に選んだ．第 2 図に見られるように， この衝擊波変位 $5 \%$ の規準は控えめである。すなわ

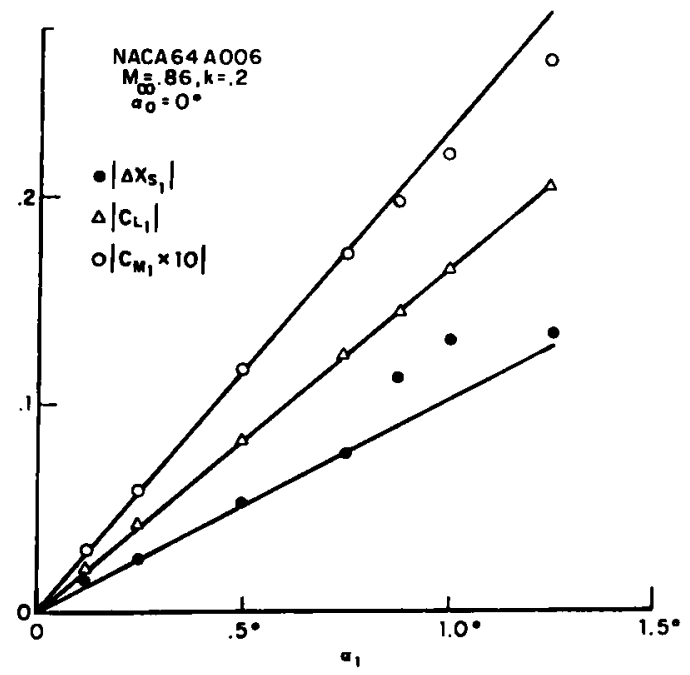

第 2 図

的空気力と衙整波運動に対する変動迎角の影留 (振幅)

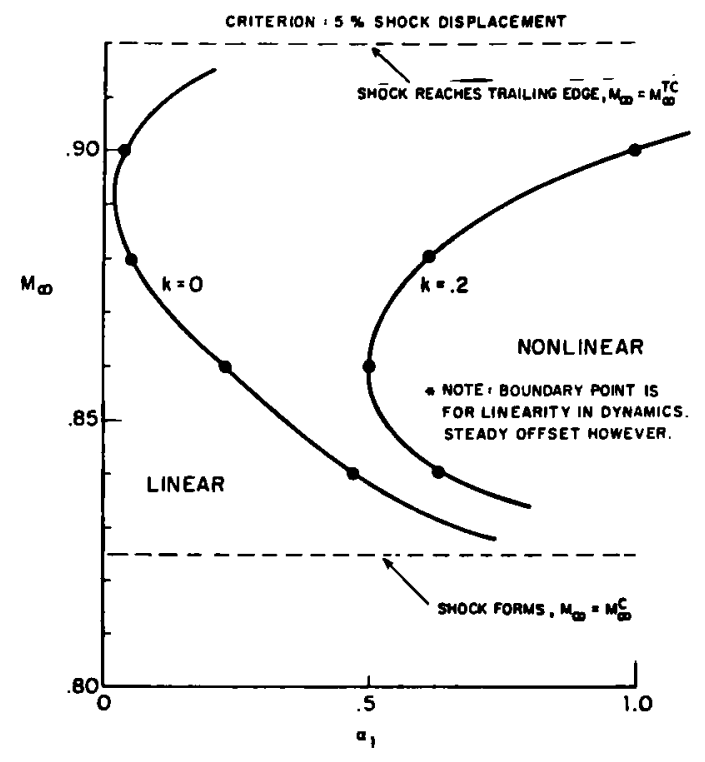

第 3 図 線形／非線形挙動の境界に対する無次元振動数の 影響（マッハ数〜変動迎角）

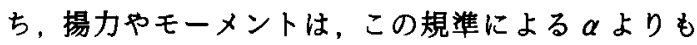
高い $\alpha$ まで、線形性を保つ傾向にある。また，この 傾向は，他の適当な規準でもってしても変わらない. しかし、衛擊波が後緑に非常に近い位置まできたとき には，この5\%規準は，修正する必要があるだろう。

$k=0$ と 0.2 について, 結果を第 3 図に示す. 定常 流れ $(k=0) て M_{\infty}=0.88$ と 0.9 の場合，線形挙動であ るためには，迎角が非常に小さくなければならないこ とに注意する.実際、これらのマッ八数の $k=0 て ゙$ は，この線形性は成立しえないようである，反面， $k$ $=0.2$ では，線形䇢囲は大きく拡がっている． $M_{\infty}<$ $M_{\infty}^{c}$ あるいは， $M_{\infty}>M_{\infty}^{\mathrm{tc}} て ゙$,すべての実用的な目的 では，線形籍囲は制限なし，となる．実際上，この範 囲ては非粘性・微小擾乱・遷音速理論の非線形性が重 要になる前に，他の物理効果，たとえば粘性などの影

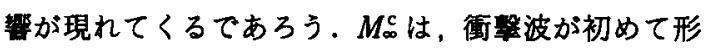
成されるマッ八数であり， $M_{\infty}^{\text {tc }}$ は，それが後緑に到達 するときのマッハ数である。

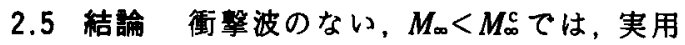
的な迎角の䇢囲を通して線形である、これはまた，衝 撃波が後緑まで移動してしまった $M_{\infty}>M_{\infty}^{\mathrm{tc}}$ ても同じ

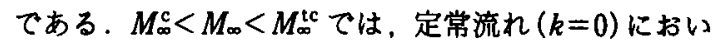
て、線形挙動の起こる迎角が非常に小さくなるような 線形／非線形の境界線が形成される.しかし, 線形挙 動の筑囲は，非定常流れについては大体增加する。

$M_{\infty}^{c}<M_{\infty}<M_{\infty}^{\text {tc }}$ の範囲では，㟟音速微小掫乱理論 (LTRAN 2)や完全ポテンシャル理論は，ある狭い $M_{\infty}$ 


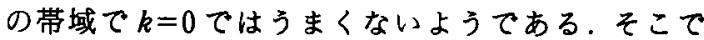
は，衝擊波変位を，したがって空気力を，相当過大に 見積もってしまう。このことは，さしあたって，理論 に粘性が含まれていないことに原因があるとされよ う.

空力伝達関数は，線形挙動に対して跾密に適用する ものであるが、非線形の動的効果が重要となってきた 場合でも，その有効性を維持できるものと考えられ る.その理由として，

1）非線形努果は，振動数が增すにつれて減少す る。

2）高い振動数では，古典的線形理論が適度に精度 があり．実際，非粘性理論は，振動数が大きくな るにつれ，古典的線形理論に近ついていく ${ }^{7,8)}$. ことが挙げられる。

低振動数䢬音速微小摄乱理論では，相似則が使え， それは必要とする多大の計算量を節減し，また，一つ の翼型に関する結果を，翼型系全体にまで普遍化する ことができる。この議論については文献 11 を参照さ れたい.

ここでは，2 次元流れを論じてきたが，一般的な考 え方ややり方は，3次元流れに対しても有効である． とくに，3 次元効果は，遷音速流についての線形挙動 範囲を拡げる要因として期待できる．たとえば，遷音 速微小摄乱理論，局所線形化，および古典理論などの 精度は, 3 次元奻果によって向上するであろう.

架力解析のいかなる遷音速の手法であっても，それ が予知し，使用する平均定常流れが，正確なものでな ければ，空力弾性屋達に有益な情報を与えることは期 待できない，したがって，実験で得られるものも含め て，現在使用可能な，最良の定常流れを，直接入力て きることが大いに望まれるところである．実験值を使 うものは，定常流れ分については，おのずと粘性効果 を含むものとなろう．とくに，平均衝擊波を正しい位 置に据えることになる。

\section{3. 逼音速流れにおける非定常振動についての多価 性，退移時間，およひ平均值}

3.1 これまでの研究 Kerlickと Nixon は文献 12 において，遷音速流れにおける振動幊についての 揚力を検討するために差分時間進行法による計算機コ ードを使用する場合，実質的な定常流れを得るまでに は，時間を十分に進める必要がある，という重要な指 摘を行った，さらに彼らは，定常状態に到達するまて の，遷移時間の推定法を示している。また，もし，逻 移が完了する前に，すなわち定常状態に至る前に時間 進行解を止めてしまったとすると，実際には起こらな
いにもかかわらず，買の振動によって平均揚力に変化 を生じた，という誤った結論を導いてしまうことを注 意している.

しかしながら，おそらく敬くべきことに，ある狭い マッ八数範囲では，遷移が衰退し定常状態に落ち着く までの時間が. 恐しく長くなる，さらに，ある非常に 狭いマッ八数範囲内では，迎角ゼロのまわりに振動す る対称翼型についての揚力の平均值が，ゼロでないこ とが起こりうるのである.

3.2 最近の研究 文献 12 では, 計算機コード

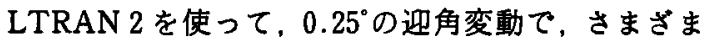
の無次元振動数 $k$ で振動する翼型のマッ八数 0.875 の自由流れについて扱っている．そこでは，平均揚力 の值が対応する振動揚力のピーク值の $1 \%$ 以下になる のに，典型的な場合，翼の振動を 6 周期まてととらなけ

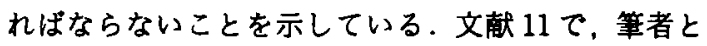
その共同研究者達は，(同じく計算機コード LTRAN 2 を使って) きまざまなマッ八数や無次元振 動数における,種々の翼型 64A 006, 64 A 010,

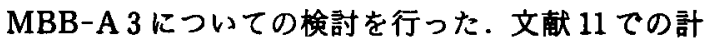
算は，翼の振動の 6 周期までを，時間方向前向きに行 っている. Kerlik と Nixonによって見いだされたよ うに，64 A 006 (対称) 翼型についての文献 11 の結果 は，振動の 6 周期で検討したほとんどのアッハ数に対 しては，振動翼についての中心すなわち平均の揚力 が、翼が振動しないときの值（すなわちぜ口）から実 䝯的に変化していないことを示している。しかし， $M_{\infty}=0.9$ では，状況が違っていた。よって筆者は， 誤って，平均揚力に変化がおきたと結論づけた．正し

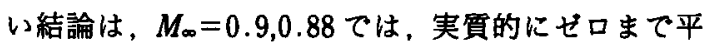
均揚力が落ち着くのに，多くの周期 $(>40)$ が必要て ある，ということである．筆者とその共同研究者がそ の後行った計算で，このことが裏づけられている。

このように，筆者は，ゼロでない平均掦力は，迎角 振動に応答する非線形空気力系において，数学的には 可能であるけれど，LTRAN 2 を使って調べたパラ メータの籍囲では，そのような揚力は観察されなかっ た，と結論づけた，しかし，あるマッ八数ては，平均 揚力が落ち着くまでの時間は, 極端に長いものとな る.

次に筆者は，Peter Goorjian ${ }^{13)}$ との議論に利すると ころが大きい，彼は，ぜ口てない平均揚力が実際起き たことを示す $M_{\infty}=0.89$ ての計算 ${ }^{5}$ を行った. Goorjianの結果は, 文献 $14 て ゙ ， よ り$ 総合的に論じられて おり，そこでは，この計算の拡張版が与えられてい る.しかるに，筆者も共同研究者であるUeda と、こ の $M_{\infty}$ について計算を行ってみた．その結果を第 4 図 


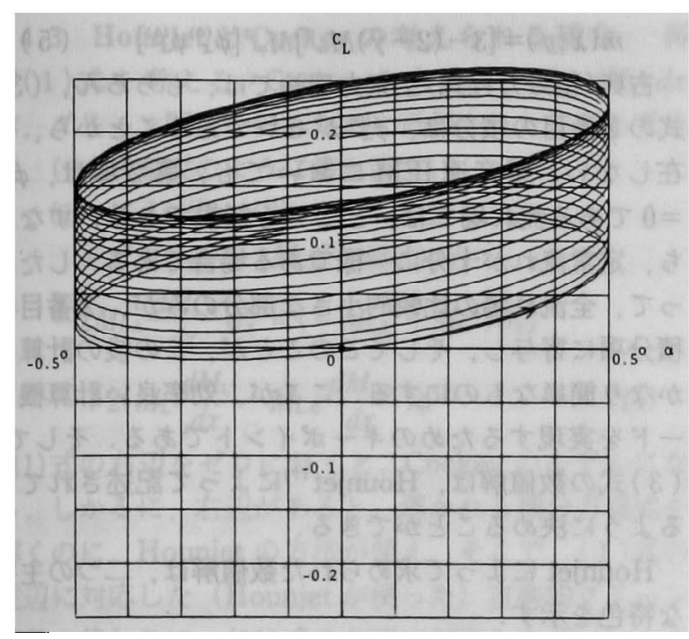

a) $N=1 \sim 20$ サイクル

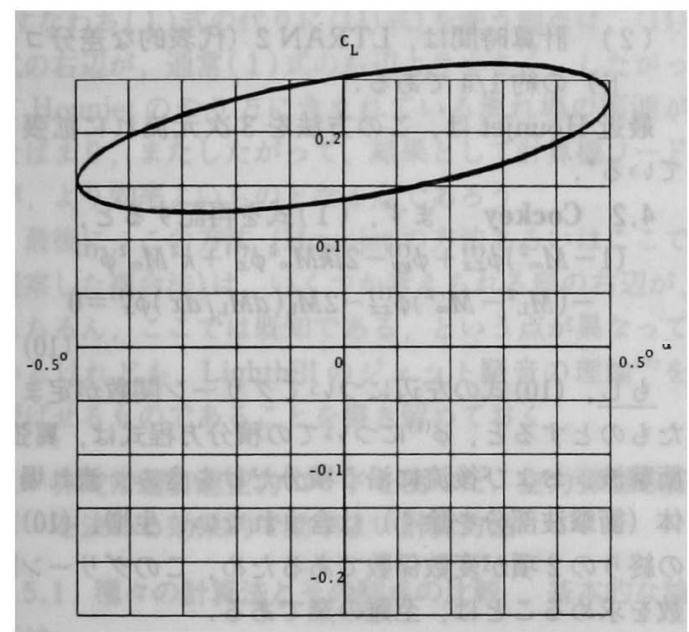

b) $N=21 \sim 40$ サイクル

第 4 図揭力のヒステリシス曲䠗〜変動迎角

NACA 64 A 006, $M_{\infty}=0.89, k=0.2$

と第 5 図に示す これらの結果は， $M_{\infty}=0.89$ で,ゼ ロでない平均揚力が確かに起こることを，明らかに示 唆している。

第 4 図に示す（ヒステリシス）曲線に浻って，時間 が変化している．見てわかるように，20周期から後 の方で平均揚力は，はっきりとゼロとは異なり，ま た，さらにそれは，振動揚力の相当量にあたる．平均 掦力は

$$
C_{\mathrm{LAVG}}=\left(C_{\mathrm{E}}^{+}+C_{\mathrm{L}}^{-}\right) / 2
$$

また，振動掦力は

$$
C_{\mathrm{L} \text { osc }}=\left(C_{\mathrm{L}}^{+}-C_{\mathrm{L}}^{-}\right) / 2
$$

と定嶬され，ここで， $C_{\mathrm{L}}^{+}, C_{\mathrm{L}}^{-}$は， $C_{\mathrm{L}}$ の時間履歴にお ける 2 個の隣接するピークのうちの，それそれ，正側

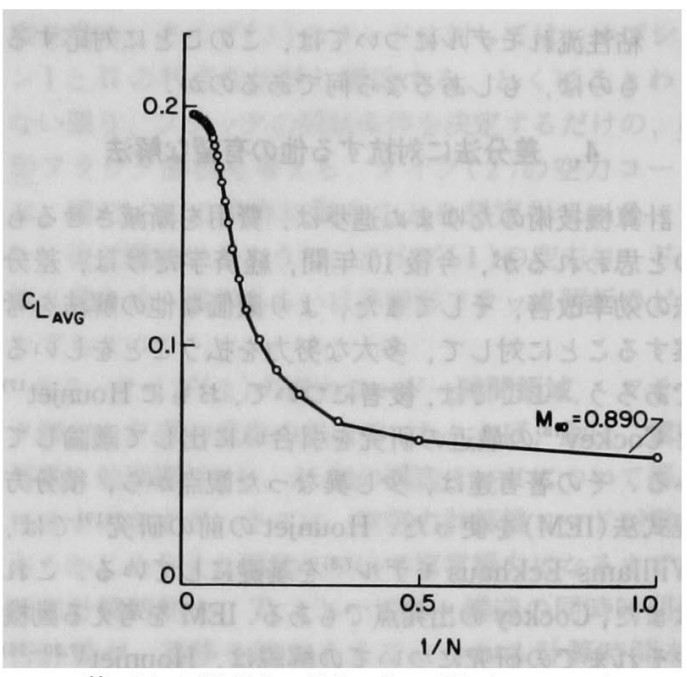

第 5 図 平均揚力〜掁劰回数の逆数 $\left(M_{\mathbf{\infty}}=0.89\right)$

と負側のピーク値を表す，第 5 図では，平均掦力を $1 / N$ に対してプロットしてあり， $N$ は，迎角振動の 周期数である.

Goorjian が説明しているように，もし，基の振動 を正てはなくて，負の初期迎角から始めたとすると， 平均揚力は，それに対応して，正ではなくて負となる (大きさは同し). 実際, ヒステリシス曲線は， $C_{\mathrm{L}}$ と $\alpha$ をともに符号返転させた 2 重鏡像となる。ささらに， もし，振動している買を，ちょうどゼロ迎角の位置で 静止させると, 平均揚力は, ある有限の值にとどま る．このことは，この単一(ゼロ)の迎角に対して，揚 力には 3 個の解が存在することを示すことになる．こ の結果と, Steinhoff と Jameson ${ }^{15)} の$ 結果とは, 完全 に符合する. 彼らは, 完全ボテンシャル方程式の直接 計算により非一義（多価）定常流れ解を得ている.

より最近, Salas ら ${ }^{16)}$ は, 定常流れについて, 完全 ポテンシャル方程式とオイラ方程式を調へた. 同しよ うな条件で，完全ポテンシャル方程式では非一義解を 見いだしたが，オイラ方程式では得られていない。し かし，数值計算という手段では，対象内のすへての可 能な条件について，非一義解が存在していないことを 証明するのは，きわめてむずかしいことである。

当然，疑問は解消されていない.

一なぜ、マッハ数の狭い範囲内で，このゼロでない 平均揚力が生じるのか. ここて, 非一義解が钼察 された $M_{\infty} \cong .89$ は， $k \rightarrow 0$ としたときに、線形挙 動が最も小さくなるマッハ数に対応していること をいっておこう，第 3 図参照.

一数学的モデル化の，もしあるとするなら，どのレ ヘルで非一義解が起こらなくなるのか.

ーこの結果は，物理的に意味があるのか．とくに， 
粘性流れモデルについては、このことに対応する ものは，もしあるなら何であるのか.

\section{4. 差分法に対抗する他の有望な解法}

計算機技術のた氻ま進歩は，費用を漸減させるも のと思われるが、今後 10 年間, 経済学たけは, 差分 法の効率改善，そしてまた，より廉価な他の解法を考 案することに対して，多大な努力を払うことをしいる であろう．ここでは，後者について，おもに Hounjet ${ }^{17)}$ と Cockey ${ }^{18)}$ の最近の研究を引合いに出して議論して みる，その著者達は，少し異なった観点から，積分方 程式法(IEM)を使った. Hounjet の前の研究 ${ }^{19)} て ゙ は ，$ Williams-Eckhaus モデル7,7)を基礎にしている。これ はまた，Cockey の出発点でもある．IEM を考える動機 やそれまての研究についての解説は, Hounjet ${ }^{17,20 ~ 26)}$ によってよくまとめられている。

Hounjet とCockeyは，ともに遷音速微小摄乱方程 式近似を用いており．その速度ポテンシャルを，定常 部 $\phi^{(0)}$ と，(翼の運動による）非定常部 $\phi^{(1)} に$ 分けた。 (無限に) 小さな (調和) 運動を仮定すると， $\phi^{(1)}$ を支配 する場の方程式は， $\phi^{(0)} に$ 依存する変数係数の線形方 程式である。すなわ方，

$$
\begin{aligned}
& \left(1-M_{\infty}^{2}\right) \phi_{x x}^{(1)}+\phi_{\phi y}^{(1)}-2 i k M_{\infty}^{2} \phi_{x}^{(1)}+k^{2} M_{\infty}^{2} \phi^{(1)} \\
& \quad=\left[\left(M_{L}^{2}-M_{\infty}^{2}\right) \phi_{x}^{(1)}\right]_{x}
\end{aligned}
$$

ここで $M_{\infty}$ は流れのマッ八数であり， $k$ は翼弦長を $c$ とする無次元振動数 $k=\omega c / 2 U$ である. $c$ は長さを 無次元化するのに使われる. $M_{\mathrm{L}}$ は局所マッ八数て

$$
M_{\mathrm{L}}{ }^{2}=M_{\infty}{ }^{2}+\left[3-(2-\gamma) M_{\infty}{ }^{2}\right] M_{\infty}^{2} \phi_{x}^{(0)}
$$

である. $\phi^{(1)}$ の添字は，空間についての微分を表す。

ここからは, Hounjet と Cockey のやり方は違った 道筋をとる.（1)式の右辺をぜロにすると，古典空気 力理論になることに注意する。

4.1 Hounjet 古典空気力学 ( $(1)$ 式左辺)のグリ

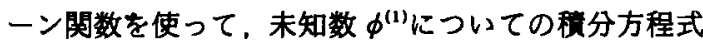
を得る。すなわち

$$
\begin{aligned}
\phi^{(1)}(x, y)= & \int_{0}^{\infty} \Delta \phi^{(1)}(u) \frac{\partial}{\partial y}[E(x-u, y ; k, M)] d u \\
& +\int_{-\infty}^{\infty} \int_{-\infty}^{\infty} m(u, v) \\
& \times E(x-u, y-v ; k, M) d u d v \quad \text { (3) }
\end{aligned}
$$

(3)式の右辺で，第 1 項は翼弦（と後流）に沿う䅡分 でり．第 2 項の積分は，全体の流れ場（下記参照） についてのものである，E は，放射条件と次式を満 たす基本解を表す。

$$
\begin{aligned}
\left(1-M_{\infty}^{2}\right) E_{x x} & +E_{y y}-2 i k M_{\infty}^{2} E_{x} \\
& +k^{2} M_{\infty}^{2} E=e^{i k x} \delta(x) \delta(y)
\end{aligned}
$$

ここで $\tilde{k} \equiv k M_{\infty}^{2} / \beta^{2} て ゙ ， m$ は次式で与えられる．

$$
m(x, y)=\left[3-(2-\gamma) M_{\infty}^{2}\right] M_{\infty}^{2}\left[\phi_{x}^{(0)} \phi_{x}^{(1)}\right]
$$

古典(積分方程式) 空気力理論では，もちろん，(3) 式の 2 番目の積分は，市がゼロであることから，存 在しない，遷音速 IEMにおいても，第 2 項は， $\phi_{x}^{(0)}$ =0である流れ場では，どこでも無視できる．すなわ ち，定常流れが十分に一様である場合である。したが って，全流れ場の比較的小さな部分のみが，2 番目の 積分項に寄与し，そしてこのことが．この後の計算を かなり簡単なものにする。ここが，効率良い計算機コ 一ドを実現するためのキーポイントである：そして，

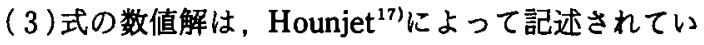
るように決めることができる。

Hounjetによって求められた数值解は，二つの主要 な特色を示す。

（1）（翼の運動における線形化に関する）精度は， 差分法によって得られるものと同程度である.

（2）計算時間は，LTRAN 2（代表的な差分コー ド）の約 1/4である。

最近 Hounjet は，この方法を 3 次元流れに执張し ている*.

$$
\begin{aligned}
& 4.2 \text { Cockey まず, (1)式を再記すると， } \\
& \left(1-M_{\infty}^{2}\right) \phi_{x x}^{(1)}+\phi_{y y}^{(1)}-2 i k M_{\infty}^{2} \phi_{x}^{(1)}+k^{2} M_{\infty}^{2} \phi^{(1)} \\
& -\left(M_{\mathrm{L}}{ }^{2}-M_{\infty}{ }^{2}\right) \phi_{x x}^{(1)}-2 M_{\mathrm{L}}\left(d M_{\mathrm{L}} / d x\right) \phi_{x}^{(1)}=0
\end{aligned}
$$

もし，(10)式の左辺についてグリーン関数が定まっ

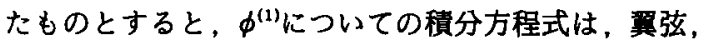
衝擊波，および後流に沿う積分たけを含み，流れ場自 体（衝撃波部分を除く）は含まれない，生增，(10)式 の終りの 2 項が変数係数であるため，このグリーン関 数を求めることは, 至難の業である.

そこで，Cockeyははグリーン関数を(近似的に) 得 るため， $M_{\mathrm{L}}$ と $d M_{\mathrm{L}} / d x$ に対する局所線形化近似によ り．（10）式を変形した．あとの計算は，積分が翼弦 （と後流）に加えて，衝撃波にも沿う以外，通常の手法 に従う.

Cockeyによって得られた結果は、二つの主要な特 色を示す。

（1）衝擊波とその動きが考慮されているにもかか わらず，精度は，差分法のそれよりかなり悪い。

（2）しかし，計算コストは，古典空気力理論にひ けをとらない。

(1)はもちろん，残念な結果である.しかしなが ら. Cockey モデルでの衝擊波の旨い組み込み方と， Hounjet $の$ 実貝的な成功は，Hounjet と Cockey の方 法の特色を組み合わせるゃり方を示唆している.

\footnotetext{
- (訳注) AIAA J., Vol.23, No. 4, 1985.
} 
4.3 Hounjetと Cockeyの考えられる統合 再

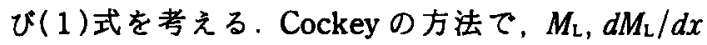
が、グリーン関数を得るために近似されたことを考え

て，(1)式を次のように書き直す。

$$
\begin{aligned}
& \left(1-M_{\infty}^{2}\right) \phi_{x x}^{(1)}+\phi_{y z}^{(1)}-2 i k M_{\infty}^{2} \phi_{x}^{(1)} \\
& \quad+k^{2} M_{\infty}^{2} \phi^{(1)}-\left(M_{\mathrm{LA}}{ }^{2}-M_{\infty}^{2}\right) \phi_{x x}^{(1)} \\
& -2 M_{\mathrm{LA}} \frac{d M_{\mathrm{LA}}}{d x} \phi_{x}^{(1)}=\left(-M_{\mathrm{LA}}{ }^{2}+M_{\mathrm{L}}{ }^{2}\right) \phi_{x x}^{(1)} \\
& \quad+2\left(M_{\mathrm{L}} \frac{d M_{\mathrm{L}}}{d x}-M_{\mathrm{LA}} \frac{d M_{\mathrm{LA}}}{d x}\right) \phi^{(1)}
\end{aligned}
$$

(11)式の右辺をゼロにおくと，Cockey のモデルにな る.しかるに，右辺があると，導かれる積分方程式を 解くのに，Hounjet の方法が使え，そこで，(1)式の 左辺に対応した（Hounjet が使った）古典的グリーン 関数の代わりに，(11)式の左辺に対応した Cockey の 近似的なグリーン関数を使う。おそらく，この複合法 (すなわち(1)式の代りに(11)式)を使う利点は，(11) 式の右辺が，通常 (1) 式の右辺より小ざく、したがつ て Hounjetのやり方に含まれている流れ場の箦囲が せばまり．またしたがって，結果として計算機コード が、より奻率よいものとなる点であろう。

最後に、この方法（Hounjet の方法あるいはここで 提案した複合法)は，いくつか考えられる形の右辺が， もちろん，ここでは既知である，という点が異なって いるけれども, Lighthill のジェット騒音の理論 ${ }^{27) を ~}$ 偲ばせるものであることを書き留めておく．

\section{5. 非定常逜音速空カコードを使った，空力弾性応答 を決める奻果的で奻率よい計算方法}

\section{1 堭々の計算法とその利点の比较 基本的な論} 点は，

ーフラッタ解析を行う前に，規定された翼の運動に 対して空カコードを走らせ, 得られた空気力のデ ータを保存して使うべきなの（オプションI）

一翼と空気力の時間履歴を同時に決めるため，棈造 動力学コードと空力コードをいっしょに走らせる である。 べきなか（オプション II）

二つのタイプの空気力計算機コードが使える.

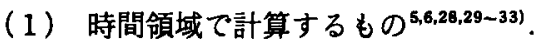

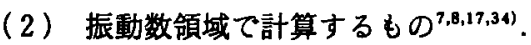

タイプ(2)のコード使用は，もちろん，オプション II の遂行を除外する，一方，タイプ(1)の計算機コード を使う方は，オプションIであってもIIであっても よい.

以下に，それぞれのタイプの計算機コードをどのよ うに使えば最も効果的であるのか，といったことで考
察を進め, タイプ(1)のコードに対しては，オプショ ンIとII の利点を比較し議論する。とくにことわら ない限り,フラッ夕の開始条件を決定するたけの，線 形フラッタ解析を考える.タイプ（2)の空カコード は、暗に、この場合に限ることを想定している。 た，後で議論するように，タイプ(1)の空カコードを 使う場合は，線形あるいは非線形フラッ夕解析のどち らでもよい.

5.2 タイブ(1)の空カコードー時間領域 フラッ 夕解が, $P$ 個の変数の組合せ (たとえば、動圧, 翼端 質量，舵面剛性）と， $M$ 個の構造モードについて得ら れるものとする.さらに，空気力計算機コードが翼の あらかじめ与えた運動について定常揚力になるまでの 所用計算時間を， $T_{\mathrm{A}}$ とし, 流体・構造の同時時間進 行計算が，遷移を終えるまでにかかる計算時間を， $T_{\mathrm{F}}$ とする． $T_{\mathrm{A}}$ と $T_{\mathrm{F}}$ の相対的大きさは，翼型形状， マッ八数 $\left(T_{\mathrm{A}}\right.$ が) あるいは，構造減衰 $\left(T_{\mathrm{F}}\right.$ が) に依 存する。一般には， $T_{\mathrm{F}}>T_{\mathrm{A}}$ であるが，例外もある。

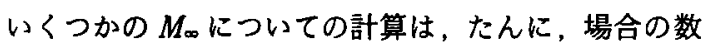
に比例して計算量がふえるだけなので，簡単のため， ある固定したマッ八数のみ考える.

では、オプションIとIIを比較して利点を考えて みよう。

5.2 .1 オプションI: 空力弾性計算前に空気カデ 一夕作成と保存 空気力を作る場合の総計算時間は,

$M * T_{\mathrm{A}}$

で，Pに独立である.フラッ夕解析自体にも，いく らか余分な時間がかかるが、それは, 空気力を作るの に要する時間に比べると，とるに足らない量である。

5.2.2 オプション II : 空気カデータと権造データ の同時作成 総計算時間は

$$
P * T_{\mathrm{F}}
$$

であり。もちろんこれは $M$ に独立である。明らか に，二つのオプションのどちらが一般に好ましいか は,

$M * T_{\mathrm{A}} \lessgtr P * T_{\mathrm{F}}$

による.オプションIIがより好ましいものとなるた めには，モード数 $M$ が，パラメータの数 $P$ より，何 がしか多くなければならない.したがって，オプショ ンIIは，設計確認計算においてより有効であり，才 プションIは，初期設計段階で，より有効となろう。

5.3 タイプ(2)の空カコードー振峌数領域 この 場合には，これまでオプションIのみが使われてきた が、下記の議論を参照されたい.

$N F$ をフラッタ解析に必要な無次元振動数の数とす る、 $T_{\mathrm{AF}}$ を、計算機コードが，一つの振動数について 空気力を決めるのに要する時間とする.モードの数が 
計算時間に影響しないように，空力影響係数法を使う ものとする゙.

$$
\begin{aligned}
& \text { オプションI : 空気力を算出する計算時間は } \\
& N F * T_{\mathrm{AF}}
\end{aligned}
$$

(2.I) と時間領域で空気力を計算する時間を比べる. 前述の議論と（1.I）を参照のこと.

$$
N F * T_{\mathrm{AF}} \gtrless M * T_{\mathrm{A}}
$$

もし， $T_{\mathrm{AF}}$ と $T_{\mathrm{A}}$ が同程度であるなら（競争によりそ のようになる傾向がうかがえる），(1.I）と（2.I）の 間でどちらを選ぶかは，空力弾性計算で必要とするモ ードの数 $M$ に対する振動数の数 $N F$ に依存する.

オプションIA：このやり方は，まだ行われたこと はないが、振動数領域の空気力をもってきて，パデ近 似，あるいはそれに相当する表現 ${ }^{35)} に よ り$ 曲線の当て はめを行い，それを用いて空気力の微分方程式表 示36,37を見いだし，それから，時間進行フラッタ解析 を行う．計算時間は，およそのところ，やはり

$$
N F * T_{\mathrm{AF}}
$$

となる. 直接的な時間進行の空力コードを使う場合の 対応する計算時間は（前議論参照）

$$
P * T_{\mathrm{F}}
$$

てある. $T_{\mathrm{AF}} \sim T_{\mathrm{F}}$ と仮定すると，必要な無次元振動 数の数に比べて，パラメータの数が多い場合には，才 プションII を使う時間領域法より，振動数領域空気 力法のほうが好ましいものとなる。
5.4 比較のまとめ
(1.I), (1.II), (2.I), (2.

IA）の推算を比較することにより，与えられた状況に おいて，どれを選択するか。ということを、初期判断 できであろう。

\section{5 非線形フラッ夕解析}

5.5.1一般的考察 もし，非線形フラッ夕解析が 必要となれば，時間領域空気力法，タイプ(1)，しか 使えない.

もちろん，空力弾性計算は，時間領域あるいは振動 数領域のどちらでも行える.しかし，オプションI と II との間には，若干のやりとりがある.オプションI では，対象とする翼の応答レベルの数，NR，という 乗数因子をさらに使わなければならない. 線形のフラ ッタ解析では，1個の応答レベルのみが対象となる （簃密には，ぜロに向かう無限小の応答レヘル).した がって，比較する計算時間は，

$$
\begin{aligned}
& \text { オプション I }: N R * M * T_{\mathrm{A}} \\
& \text { オプション II }: P * T_{\mathrm{F}}
\end{aligned}
$$

さらに，非線形フラッ夕解析の場合には，パラメー 夕の数, $P$, が, 線形フラッタ解析より, 何がしか多

\footnotetext{
・もし空カマトリックスの逆行列と直接とらずに，縀和法を 使うとすると，新たな問逼が生じる。
}

くなる傾向にあることを注意しておく， ィ川

このニつのオプションが相対的にどちらがよいか， については，オプションIに現れる因子 $N R$ の分だ けオプションIIに向く傾向にあること以外，前と同 じである.非線形フラッタ解析において，オプション I を使えば，実際，振動数領域でのフラッ夕解析にな り,よるところの方法論は, 文献 38 と 39 に記述され ている.もちろんこの方法論は，翼の応答レベルが小 さいとき，古典的な振動数領域のフラッタ解法に還元 する.最近行われるオプションIIによる解法は、そ のままわかりやすいもので、ここではとくにこれ以上 ふれない。また，次のことをいっておくへきであろ j.

- 振動数領域の非線形フラッタ解析ては, 通常, 時間領域解析の近似より多くの近似を導入する。 しかし。

・幸いにして、線形のフラッタ解析は，それてよ くこと足りるものであり，したがって，質問全部 が、しばしば疑問の対象となってしまうことがあ る.

\section{6. 結論}

6.1 現时点での解答 本論は，四つの質問から始 めた．これらに対する解答は，将来必ずや洗練されて いくものと思われる.しかし，現在までの知識に基づ く，部分的な答としては，次のようなるだろう.

○翼の十分に小さな運動（翼弦長の $5 \%$ 以下の十 分小さな衝擊波運動まで) に対しては，空気力は 翼の運動に関して線形関数となる

○遥音速微小按乱と完全ボテンシャル流れの解 の，ある条件下で観察される非一義性は，支配方 程式そのものに内在し，解法の数値的な所産では ない213 16).オイラ方程式ては, 今日まてこれに 対応する解の非一義性は観察されていない。しか し現時点て、、ホテンシャル流れの方程式解におけ る非一義性が，ある条件て，オイラ方程式の解に も，あまり劇的ではない(あるいは同しくららいの) 形にしろ，あるかないかを見きわめるのはむずか しい.これは、今後の研究としての重要な課題* でる。ささらに、もしあるとするなら，そのよう な解の物理的意味を明らかにしなければならな い.

○差分法に対抗しうる有望な方法は, 少なくとも 一つ使えよう. Hounjet のフィールドパネル法で

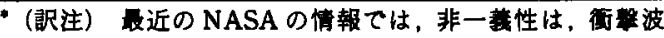
の等エントロピの仮定に憘因するという結論になりつつあ るよらてある。
} 
ある、この方法は，まだいつそうの改善が期待さ れる。それはここで議論したようにCockey ${ }^{18)}$ の研究であるかもしれず，また，3次元流れへの 拡張でもあるだろう 差分法対有限要素法対フィ ールドパネル法の相対的利点については，今後の 課題であり、これは，まちがいなく活発な論議を 呼ぶものと思われる。

○空力弾性応答を決めるため，流体および構造の 運動方程式を連立させて，時間について皘分する オプションは，いくつかの応用に対しては魅力あ るものである一方, 振動数領域のフラッタ解析も 依然として重要であり，ときにはより魅力的なオ プションにもなりうる. 振動数領域の空気力を作 り出す方法として使えるものは，

- あらかじめ無限小調和翼運動を仮定する空力 法 $7,8,17,38)$

- 時間進行空力コートによって得られる単一の時 間履歴記録から，振動数領域のデータを作り出 す，インパルス〜伝達関数の考方方 ${ }^{38 \sim 40)}$.

○空力弾性解析については，相対的計算時間の簡 単なオーダ評価が可能で，本論の中で議論され た. 線形のフラッ夕解析は，遷音速流れの領

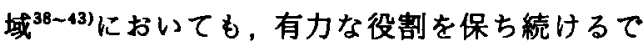
あろう.

6.2 今後の課題 なすべき研究課題は，枚挙にい とまがない。ここでは，対象としている流体および空 力弾性現象の物理的なモデル化と解釈を，それらに共

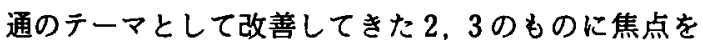
絞ることにする。

・ ポテンシャル流れの解と，オイラ方程式の解に おいて，前者が非一義解を呈する条件で，両者が 表す定性的な差異をよく理解する必要がある。こ の差異を理解し解决するまで、これは，非一義解 が涀察される条件て、粘性の修正のためにポテン シャル流れの解と境界層修正を組み合わせるよう な方法すべてに，筑問を投げかけることになる。

・オイラ方程式のためのより有奻な（奻率よい） 解法をいかに考案するか，ということが，互いに 補いあう論点でもある. MagnusとYoshihara ${ }^{41}$ の先駆的業績から後，みるへきものはない。

いくつかの見込のある利点を持った可能性のあ る方法は，非線形の平均定常流れに，小さな（無 限小）線形の動的擾乱がつけ加わったものとして 流れを扱ってもよい，と仮定する方法がある。こ のやり方は. Williams ${ }^{7,8)}$, Fung と Seebass ${ }^{9)}$, Hounjet $^{17)}$, Ehlers とWeatherill ${ }^{34)}$ 等によって. ポテンシャル流に対して効果的に使われている.
この方法はまた，Lighthill ${ }^{45)}$, Williams 他“年等に よって，パネルフラッ夕（揚力なし）や揚力面空 気力において境界層効果をモデル化するのに，そ の一つの極限的な形で使われている.

こうすることで，変数係数（空間依存）をもつ 線形の時間依存偏微分方程式の組に帰着すること ができる．それは，平均定常流については，その 代り，時間に依存しない非線形偏微分，オイラ方 程式によっている．この方法の期待される利点と して次の事柄を挙げることができる。

○動的擾乱方程式とその解のために使う入力デー 夕を準備するのに、既存あるいは将来の定常流れ コードを最大限利用することができる（もし、動 的摃乱流れについても差分法を使えぱ，平均定常 流れの差分格子がそのまま使える)。

○拡張と一般化を必要とするが変数係数の線形微 分方程式の解法を使うことができる. Hounjet ${ }^{17)}$ やWilliams 等 ${ }^{6)}$ の研究を参照されたい.

○ 線形の動的方程式を解くことは,

- 空力弾性屋の（オイラ方程式の文脈内での）要 求を，おそらく満たすであろうし，

- 平均定常流れのモデル化において，すなわち，

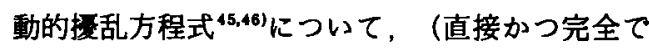
はなく）間接的また部分的に粘性効果を含めるこ とができる．さらに

- 平均定常流れそのものの動安定を調べことが でき，またそのことにより，オイラ方程式の非一 義解の見通しについてのより深い理解に資するこ とができよう。

\section{参考文献}

1) Tijdeman, H.: Investigation of the Transonic Flow around Oscillating Airfoils, Ph. D. Thesis, Delft University, Dec. 1977

2) Tijdeman, H. and Seebass, R. : Transonic Flow Past Oscillating Airfoils, Ann. Rev. Fluid Mech., 12 (1980), pp. 181-222.

3) Seebass, R. : Advances in the Understanding and Com putation of Unsteady Flows, Presented at the Interna tional Symposium on Recent Advances in Aerodynamics and Aeroacoustics, Stanford University, August 22-26, 1983.

4) McCroskey, W. J. : Unsteady Airfoils, Ann. Rev. Fluid Mech., 14 (1982), pp.285-311.

5) Ballhaus, W. F. and Goorjian, P. M. : Implicit Finite Difference Computations of Unsteady Transonic Flows about Airfoils, AIAA J., 15 (1977), pp.1728-1735.

6) Ballhaus, W. F. and Goorjian, P. M. : Efficient Solution of Unsteady Transonic Flows about Airfoils, Paper 14, AGARD Conference Proceedings No. 226, Unsteady Airloads in Separated and Transonic Flows, 1978.

7) Williams, M. H. : The Linearization of Transonic Flows Containing Shocks, AIAA J., 17 (1979), pp. 394397. 
8) Williams, M. H. : Unsteady Thin Airfoil Theory for Transonic Flows with Embedded Shocks, AIAA J., 18 (1980), pp. 615-624: Unsteady Airloads in Supercritical Transonic Flows, Proceedings of the AIAA/ASME/ ASCE 20 th Structures, Structural Dynamics and Materials Conference, St. Louis, Mo., April 1979.

9) Fung, K. Y., Yu, N. J. and Seebass, R. : Small Unsteady Perturbations in Transonic Flows, AIAA J., 16 (1978), pp.815-822.

10) Davis, S. S, and Malcomb, G. : Experiment in Unsteady Transonic Flows, Proceedings of the AIAA/ASME/ ASCE 20 th Structures, Structural Dynamics and Materials Conference, St. Louis, Mo., April 1979.

11) Dowell, E. H., Bland, S. R. and Williams, M. H. : Linear/ Nonlinear Behavior in Unsteady Transonic Aerodynamics, AIAA J., 21 (1983), pp. 38-46.

12) Kerlick, G. D. and Nixon, D. : Mean Values of Unsteady Oscillations in Transonic Flow Calculations, AIAA J., 19 (1981), pp. 1496-1498.

13) Goorjian, P. M. : Private communication, NASA Ames Research Center.

14) Dowell, E. H., Ueda, T. and Goorjian, P. M. : Transient Decay Times and Mean Values of Unsteady Oscillations in Transonic Flow, AIAA J., 21 (1983), pp. 1762-1764.

15) Steinhoff, J. and Jameson, A. : Multiple Solutions of the Transonic Potential Flow Equations, AIAA Paper No. 81-1019, AIAA Computational Fluid Dynamics Conference, Palo Alto, CA, June 1981

16) Salas, M. D., Jameson, A. and Melnik, R. E. : A Com. parative Study of the Nonuniqueness Problem of the Potential Equation, Presented at the 6 th AIAA CFD Conference, Danvers, Mass., July 13-15, 1983.

17) Hounjet, M. H. L. : A Field Panel Method for the Calculation of Inviscid Transonic Flow about Thin Oscillating Airfoils with Shocks, NLR MP 81043 U, National Aerospace Laboratory, Netherlands, Presented at the International Symposium on Aeroelasticity, Nuremburg, October 5-7, 1981, Germany.

18) Cockey, W. D. : Panel Method for Perturbations of Transonic Flows with Finite Shocks, Ph. D. Thesis, Princeton University, June 1983

19) Hounjet, M. H. L. : A Transonic Panel Method to Determine Loads on Oscillating Airfoils with Shocks, AIAA J., 19 (1981), pp. 559-566.

20) Morino, L. : A General Theory of Unsteady Compressible Potential Aerodynamics, NASA CR-2464, December (1974).

21) Morino, L. and Tseng, K. : Time-domain Green's Function Method for Three-dimensional Non-linear Subsonic Flows, AIAA Paper 78-1204 (1978)

22) Albano, E. and Rodden, W. P. : A Doublet Lattice Method for Calculating Lift Distribution on Oscillating Wings in Subsonic Flows, AIAA J., 7 (1969), pp. 279-285.

23) Nixon, D. : Calculation of Unsteady Transonic Flows Using the Integral Equation Method, AIAA Paper 78-13, January (1978).

24) Voss, R. : Time-linearized Calculation of Two-dimensional Unsteady Transonic Flow at Small Disturbances, DFLVR FB-81-01 (1981).

25) Williams, M. H. : Unsteady Thin Airfoil Theory for Transonic Flows with Embedded Shocks, Department of Mechanical and Aerospace Engineering, Report No. 1376, Princeton University, May 1978.

26) Liu, D. D. : A Lifting Surface Theory Based on an Unsteady Linearized Transonic Flow Model, AIAA Paper 78-501 (1978).

27) Goldstein, M. E. : Aeroacoustics, McGraw-Hill Book
Co., New York, 1976.

28) Houwink, R. and van der Vooren, J. : Improved Version of LTRAN 2 for Unsteady Transonic Flow Computations, AIAA J., 18 Aug. (1980), pp. 1008-1010.

29) Hessenius, K. A. and Goorjian, P. M. : Validation of LTRAN 2-HI by Comparison with Unsteady Transonic Experiment, AIAA J., 20 May (1981), pp. 731-732.

30) Borland, C. J. and Rizzetta, D. P. : Transonic Unsteady Aerodynamics for Aeroelastic Applications, Vol. I, Technical Development Summary, AFWAL TR 803107, Vol. I, June (1982).

31) Borland, C. J. and Rizzetta, D. P. : Nonlinear Transonic Flutter Analysis, AIAA Journal, 20 (1982), pp. 16061615.

32) Borland, C. J., Rizzetta, D. P. and Yoshihara, H. : Numerical Solution of Three-dimensional Unsteady Transonic Flow over Swept Wings, AIAA J., 20 (1982), pp. $340-347$.

33) Rizzetta, D. P. and Borland, C. J. : Unsteady Transonic Flow over Wings Including Inviscid/Viscous Interactions, AIAA J., 21, March (1983), pp. 363-371

34) Ehlers, F. E. and Weatherill, W. H. : A Harmonic Analy sis Method for Unsteady Transonic Flow and Its Application to the Flutter of Airfoils, NASA-CR-3537 (1982).

35) Dowell, E. H. : A Simple Method for Converting Frequency.Domain Aerodynamics to the Time Domain, NASA TM 81844 (1980).

36) Tran, C. T. and Petot, M. : Semi-empirical Model for the Dynamic Stall of Airfoils in View of the Application of Responses of a Helicopter Blade in Forward Flight, Paper 48, Proceedings, 6 th European Rotorcraft and Powered-lift Aircraft Forum, Bristol, England, 1980.

37) McIntosh, S. : Private communication.

38) Ueda, T. and Dowell, E. H. : Flutter Analysis Using Nonlinear Aerodynamic Forces, AIAA Paper 82-0728 (1982)

39) Ueda, T. and Dowell, E. H. : Describing Function Flutter Analysis for Transonic Flow: Extension and Com. parison with Time Marching Analysis, AIAA Paper 830958 (1983).

40) Ballhaus, W. F. and Goorjian, P. M. : Computation of Unsteady Transonic Flows by the Indicial Method, AIAA J., 16 (1978), pp. 117-124.

41) Yang, T. Y., Guruswamy, P., Striz, A. G. and Olsen, J. J. : Flutter Analysis of a NACA 64 A 006 Airfoil in Small Disturbance Transonic Flow, J. Aircraft, 17 (1980), pp. 225-232.

42) Edwards, J. W., Bennett, R. M., Whitlow, W., Jr. and Seidel, D. A. : Time-Marching Transonic Flutter Solutions Including Angle-of-Attack Effects, AIAA Paper 82 -0685, Presented at the 23 rd SDM Conference, New Orleans, LA, May 1982.

43) Bland, S. R. and Edwards, J. W. : Airfoil Shape and Thickness Effects on Transonic Airloads and Flutter, AIAA SDM Conference in Lake Tahoe, CA, May 1983, AIAA Paper no. 83-0959.

44) Magnus, R. J. and Yoshihara, H. : Calculation of Transonic Flow Over an Oscillating Airfoil, AIAA Paper 7598, Jan. (1975)

45) Lighthill, M. J. : On Boundary Layers and Upstream Influence, II : Supersonic Flows without Separation, Proc. Royal Soc., A217, May (1953), pp. 478-507.

46) Williams, M. H., Chi, M. R., Ventres, C. S. and Dowell, E. H. : Aerodynamic Effects of Inviscid Parallel Shear Flows, AIAA J., 15 (1977), pp. 1159-1166. 